\title{
OPEN Author Correction: Quantification of Water Flux in Vesicular Systems
}

\author{
Christof Hannesschläger $(\mathbb{D}$, Thomas Barta, Christine Siligan \& Andreas Horner $(\mathbb{D}$ \\ Correction to: Scientific Reports https://doi.org/10.1038/s41598-018-26946-9, published online 04 June 2018
}

This Article contains an error in Figure 1, where the correction factor for approximate model d is incorrect. The correct Figure 1 appears below.

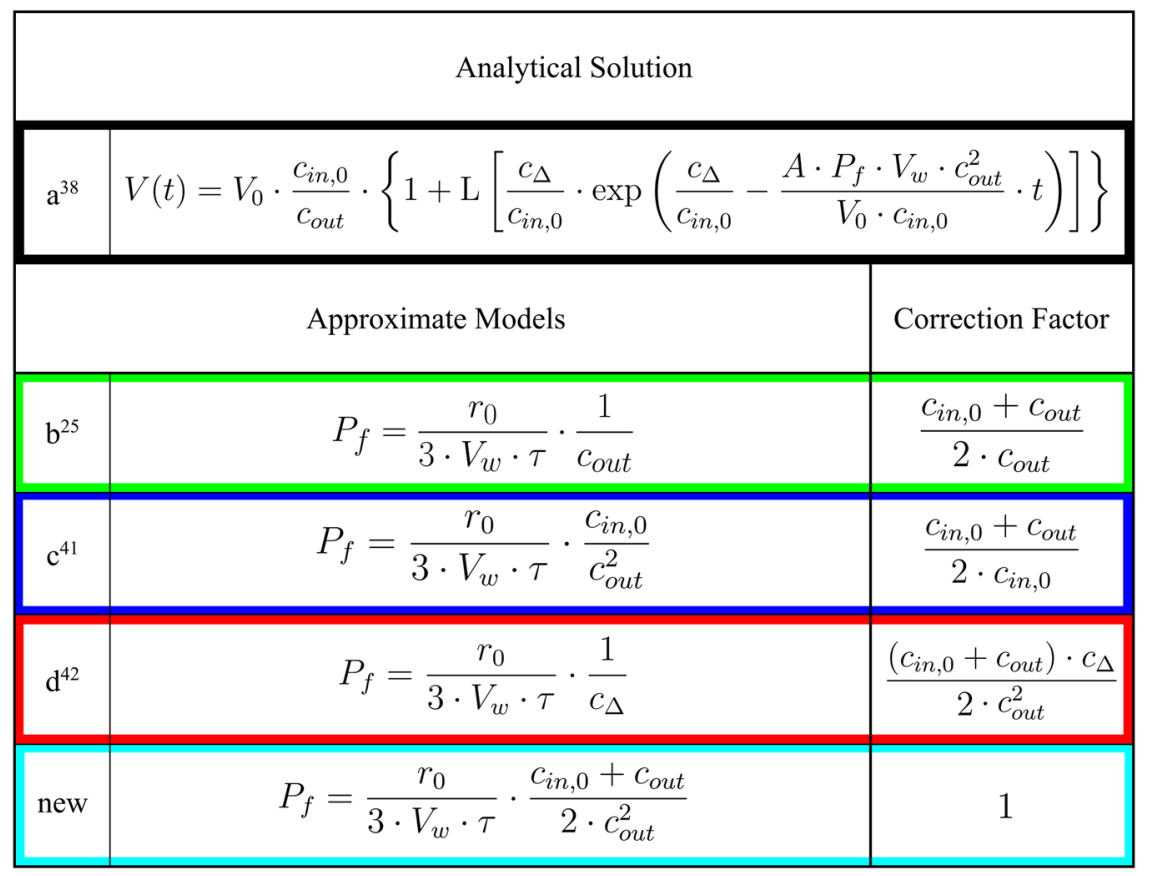

Figure 1.

(i) Open Access This article is licensed under a Creative Commons Attribution 4.0 International C. License, which permits use, sharing, adaptation, distribution and reproduction in any medium or format, as long as you give appropriate credit to the original author(s) and the source, provide a link to the Creative Commons license, and indicate if changes were made. The images or other third party material in this article are included in the article's Creative Commons license, unless indicated otherwise in a credit line to the material. If material is not included in the article's Creative Commons license and your intended use is not permitted by statutory regulation or exceeds the permitted use, you will need to obtain permission directly from the copyright holder. To view a copy of this license, visit http://creativecommons.org/licenses/by/4.0/.

(C) The Author(s) 2020 